TITLE:

\title{
Phosphodiesterase inhibitors are neuroprotective to cultured spinal motor neurons(Abstract_要旨)
}

\section{$\operatorname{AUTHOR(S):~}$}

Nakamizo, Tomoki

\section{CITATION:}

Nakamizo, Tomoki. Phosphodiesterase inhibitors are neuroprotective to cultured spinal motor neurons. 京都大学, 2003, 博士 (医学)

ISSUE DATE:

2003-03-24

URL:

http://hdl.handle.net/2433/148692

RIGHT: 


\section{【284 】}

氏 名 中か 溝知樹

学位(専攻分野) 博士 (医学)

学位記番号医 博 第 2569 号

学位授与の日付平 成 15 年 3 月 24 日

学位授与の要件 学 位 規 則第 4 条第 1 項 該当

研究科. 専攻医学研究科脳統御医科学系専攻

学位論文題目 Phosphodiesterase inhibitors are neuroprotective to cultured spinal motor neurons

(ホスホジエステラーゼ阻害薬は培養運動ニューロンに対して神経保護作用 を有する)

論文調査委員 教 授金子武 嗣教 授 橋 本 信夫 教 授 柴 崎 浩

\section{論文内容の要旨}

筋萎縮性側索硬化症（ALS）における神経細胞変性・神経細胞死の機序を明らかにし，ALSの進行を抑制する新しい治 療法の糸口を見出すことを目的として研究を行った。

ALSにおける運動ニューロン死の機序のひとつとして興奮性神経毒性の関与が言われている。これまでの研究によりラ ット脊髄初代培養系において，運動ニューロンは非運動ニューロンに比べ慢性興奮性神経毒性に対して脆弱であることが示 されている。この脆弱性は，サイクリック GMP（cGMP）を介した神経細胞保護効果が運動ニューロンにおいては非運動 ニューロンに比べ働きにくいことが原因であると考えられた。ところがさらに実験を行うと急性のラジカル毒性に対しては cGMP を全た保護効果は運動ニューロンに対しても非運動ニューロンと同様に有効であることが示された。

本研究では cGMPの分解酵素であるホスホジェステラーゼ（PDE）阻害薬を投与した場合の培養運動ニューロン保護効 果を検討した。慢性グルタミン酸毒性に対してはPDE 阻害薬は運動ニューロン，非運動ニューロンいずれについても保護 効果を認めた。PDEのアイソザイム選択的阻害薬を用いた検討では PDE5 選択的阻害薬には運動ニューロン保護効果が認 められたが，PDE1-4 選択的阻害薬には保護効果は認められなかった。一方 cGMP アナログである $8 \mathrm{br}-\mathrm{cGMP} は$ 非運動ニ ューロンのみに保護効果があった。急性ラジカル毒性に対しては PDE 阻害薬, $8 \mathrm{br}-\mathrm{cGMP}$ どちらも運動ニューロン，非運 動ニューロン両方に保護効果があった。これらの保護効果は cGMP の下流にある cGMP 依存性タンパクキナーゼ（PKG） の阻害薬であるKT5823 によって阻害され，PDE 阻害薬による神経細胞保護効果にはPKGが関与していることが示唆さ れた。免疫組織化学的に検討すると, PDE5 と PKG は临䯣全ニューロンに存在しており，2重染色を行うとその局在はニ ユーロンのマーカーである NeuN と極めてよく致していた。蛍光免疫染色の蛍光輝度を半定量的に解析すると，PKG 染色 の輝度は運動ニューロン, 春髄後角ニューロン間で差がなかったが, PDE5 染色の輝度は運動ニューロンでは後角ニューロ ンに比べ有意に高く, PDE5 は運動ニューロンに豊富に存在していることが示唆された。

以上の結果から，運動ニューロンではPDE5 が非運動ニューロンに比べ豊富なために cGMPが分解されやすく，このた め慢性興舊性神経毒性に対して脆弱である可能性が考えられた。また, PDE5 選択的阻害薬による ALS 治療の可能性が示 唆された。

\section{論文審査の結果の要旨}

本研究では，初代培養脊髄簐動ニューロンの慢性興奮性神経毒性に対する脆弱性の 1 つの機序として，cGMPを介した 神経保護効果の関与を検討した。慢性興奮性毒性に対しては，cGMPの分解酵素であるホスホジエステラーゼ（PDE）の 阻害薬は運動ニューロンと非運動ニューロンのいずれに対しても保護効果を認めた。アイソザイム選択的阻害薬を用いた検 討から, 特にPDE5 が関与していることが示唆された。一方, cGMP アナログは非運動ニューロンのみに保護効果があっ た。急性ラジカル毒性に対してはPDE 阻害薬および cGMP アナログのどちらも運動ニューロン，非運動ニューロン両方 
に保護効果があった。これらの保護効果は cGMP 依存性タンパクキナーゼ（PKG）の阻害薬によって阻害され, PKGが 関与していることが示唆された。免疫染色を行うと, PDE5 と PKG は脊髄全ニューロンに存在しており, 染色の蛍光輝度 を半定量的に解析すると, PDE5 染色の輝度は運動ニューロンでは後角ニューロンに比べ有意に高かった。以上の結果から， 運動ニューロンでは, PDE5 が非運動ニューロンに比べ豊富なためにcGMP が分解されやすく，このため慢性興奮性神経 毒性に対して脆弱である可能性が考えられた。同時に，本実験からはPDE5 阻害薬によるALS 治療の可能性が示唆された。 以上の研究は筋萎縮性側索硬化症の病態の解明に貢献し, 同疾患の治療法の開発に寄与するところが多い。したがって本 論文は博士 (医学) の学位論文として価値あるものと認める。

なお，本学位授与申請者は，平成15年 1 月 17 日実施の論文内容とそれに関連した試問を受け，合格と認められたものであ る。 